This is an electronic reprint of the original article. This reprint may differ from the original in pagination and typographic detail.

Author(s): Lips, Felicitas; Mansikkamäki, Akseli; Fettinger, James C.; Tuononen, Heikki; Power, Philip P.

Title: $\quad$ Reactions of Alkenes and Alkynes with an Acyclic Silylene and Heavier Tetrylenes under Ambient Conditions

Year: $\quad 2014$

Version:

Please cite the original version:

Lips, F., Mansikkamäki, A., Fettinger, J. C., Tuononen, H., \& Power, P. P. (2014). Reactions of Alkenes and Alkynes with an Acyclic Silylene and Heavier Tetrylenes under Ambient Conditions. Organometallics, 33(21), 6253-6258.

https://doi.org/10.1021/om500947x

All material supplied via JYX is protected by copyright and other intellectual property rights, and duplication or sale of all or part of any of the repository collections is not permitted, except that material may be duplicated by you for your research use or educational purposes in electronic or print form. You must obtain permission for any other use. Electronic or print copies may not be offered, whether for sale or otherwise to anyone who is not an authorised user. 


\title{
Reactions of alkenes and alkynes with an acyclic silylene and heavier tetrylenes under ambient conditions
}

Felicitas Lips,${ }^{\dagger}$ Akseli Mansikkamäki,,${ }^{\ddagger}$ James C. Fettinger,${ }^{\dagger}$ Heikki M. Tuononen, ${ }^{\ddagger}$ Philip P. Power ${ }^{\dagger}$

${ }^{\dagger}$ Department of Chemistry, University of California, Davis, One Shields Avenue, Davis, California 95616, United States

tDepartment of Chemistry, University of Jyväskylä, P.O. Box 35, FI-40014 Jyväskylä, Finland

\begin{abstract}
Cycloaddition reactions of the acyclic silylene $\mathrm{Si}\left(\mathrm{SAr}^{i \mathrm{Pr}_{4}}\right)_{2}$ with a variety of alkenes and alkynes were investigated. Its reactions with the alkynes phenylacetylene, diphenylacetylene, and the diene 2,3-dimethyl-1,3-butadiene yielded silacycles $\left(\mathrm{Ar}^{\mathrm{iPr}}{ }_{4}\right)_{2} \mathrm{Si}(\mathrm{CH}=\mathrm{CPh})$ $\left(\mathrm{Ar}^{\mathrm{iP} \mathrm{P}_{4}} \mathrm{~S}\right)_{2} \mathrm{Si}(\mathrm{PhC}=\mathrm{CPh})$

and $\left(\mathrm{Ar}^{i \mathrm{Pr}_{4}} \mathrm{~S}_{2}\right)_{2} \mathrm{SiCH}_{2} \mathrm{C}(\mathrm{Me}) \mathrm{C}(\mathrm{Me}) \mathrm{CH}_{2}$ (3) at ambient temperature. The compounds were characterized by X-ray crystallography, ${ }^{1} \mathrm{H},{ }^{13} \mathrm{C}$ and ${ }^{29} \mathrm{Si}$ NMR spectroscopy, and IR spectroscopy. The silylene $\mathrm{Si}\left(\mathrm{SAr}^{i \mathrm{Pr}_{4}}\right)_{2}$ did not react with more substituted alkenes such as propene, Z-2-butene, tert-butyl ethylene, cyclopentene, 1-hexene, or the alkyne bis(trimethylsilyl)acetylene under the same reaction conditions. The germylene $\mathrm{Ge}\left(\mathrm{SAr}^{\mathrm{Me}_{6}}\right)_{2}$ and stannylene $\mathrm{Sn}\left(\mathrm{SAr}^{\mathrm{Me}_{6}}\right)_{2}$ analogues of $\mathrm{Si}\left(\mathrm{SAr}^{\mathrm{Me}_{6}}\right)_{2}$ displayed no reaction with ethylene. Quantum chemical calculations using model tetrylenes $\mathrm{E}(\mathrm{SPh})_{2}(\mathrm{E}=\mathrm{Si}$,
\end{abstract}


$\left.\mathrm{Ge}, \mathrm{Sn} ; \mathrm{Ph}=\mathrm{C}_{6} \mathrm{H}_{5}\right)$ show that cyclization reactions are endothermic in the case of germanium and tin derivatives but energetically favored for the silicon species.

\section{INTRODUCTION}

Silacycles have been studied because of their importance in organic syntheses and their ability to effect stereospecific, stereoselective, regioselective, and chemoselective carbon-carbon bond formations under mild conditions. ${ }^{1-3}$ Silacycles can be obtained by the addition of silylenes to unsaturated hydrocarbons. The groups of Gaspar and Seyferth reported first examples of stable silacyclopropenes by the addition of silylenes to alkynes in $1976 .{ }^{4,5}$ The reaction of silylenes with alkenes afford silacyclopropanes (also called siliranes $)^{6}$ and were first synthesized by Seyferth in $1972 .{ }^{7}$ Both the silacyclopropenes and silacyclopropanes are formed in a concerted stereospecific manner via [2+1] cycloadditions. ${ }^{8}$ Additions of 1,3-dienes to silylenes have been found to depend on the steric bulk of the silylene subsituents. The reaction of $\mathrm{Si}(\mathrm{Mes}) \mathrm{Tbt}$ (Mes $=2,4,6$ trimethylphenyl; Tbt $=$ 2,4,6-tris $\{$ bis(trimethylsilyl)methyl $\}$ phenyl) with isoprene proceeds via a $[2+1]$ cycloaddition to yield a vinylsilirane that rearranges to a silacyclopent-3-ene. ${ }^{8 b, 9}$ However, for a more sterically crowded dialkylsilylene 2,2,5,5tetrakis(trimethylsilyl)silacyclopentan-1,1-diyl, a direct [4+1] cycloaddition occurred to yield silacyclopent-3-ene. ${ }^{10}$

In our previous investigations on the addition of the acyclic silylenes $\mathrm{Si}\left(\mathrm{SAr}^{\mathrm{Me}_{6}}\right)_{2}{ }^{11}$ and $\mathrm{Si}\left(\mathrm{SAr}^{i \mathrm{Pr}_{4}}\right)_{2}{ }^{12}$ to the alkenes ethylene and norbornadiene, we obtained the silirane compounds $\left(\mathrm{Ar}^{i \mathrm{Pr}_{4}} \mathrm{~S}\right)_{2} \mathrm{Si}\left(\mathrm{CH}_{2}\right)_{2}$ and $\left(\mathrm{Ar}^{\mathrm{Me}_{6}} \mathrm{~S}\right)_{2} \mathrm{Si}\left(\mathrm{C}_{7} \mathrm{H}_{8}\right)$. The first species features unique reversible binding to ethylene in toluene solutions with a Gibbs free 
energy of association ( $\Delta G_{\text {assn }}$ ) of $-24.9 \pm 2.5 \mathrm{~kJ} \mathrm{~mol}^{-1},{ }^{13}$ a value low enough to be greatly affected by entropic effects.

\section{RESULTS AND DISCUSSION}

Herein we report on the reactivity of the acyclic silylene $\mathrm{Si}\left(\mathrm{SAr}^{i \mathrm{P}_{4}}\right)_{2}$ with several alkenes and alkynes (Scheme 1). For the alkynes phenylacetylene and diphenylacetylene, the silirene compounds $\left(\mathrm{Ar}^{i \mathrm{Pr}_{4}}{ }_{4}\right)_{2} \mathrm{SiC}(\mathrm{H}) \mathrm{C}(\mathrm{Ph})(\mathbf{1})$ (Figure 1) and $\left(\mathrm{Ar}^{i \mathrm{Pr}_{4}} \mathrm{~S}\right)_{2} \mathrm{SiC}(\mathrm{Ph}) \mathrm{C}(\mathrm{Ph})(\mathbf{2})$ (Figure 2) were obtained at ambient temperature in toluene solutions. The reaction of $\mathrm{Si}\left(\mathrm{SAr}^{i \mathrm{Pr}_{4}}\right)_{2}$ with the butadiene 2,3-dimethyl-1,3-butadiene in toluene affords the silacyclopentene $\left(\mathrm{Ar}^{i \mathrm{Pr}_{4}} \mathrm{~S}_{2} \mathrm{SiCH}_{2} \mathrm{C}(\mathrm{Me}) \mathrm{C}(\mathrm{Me}) \mathrm{CH}_{2}\right.$ (3) (Figure 3) in a [4+1] cycloaddition reaction. However, the reactions of $\mathrm{Si}\left(\mathrm{SAr}^{i \mathrm{P}_{4}}\right)_{2}$ with the bulkier alkyne bis(trimethylsilyl)acetylene did not result in a new silirene product. 

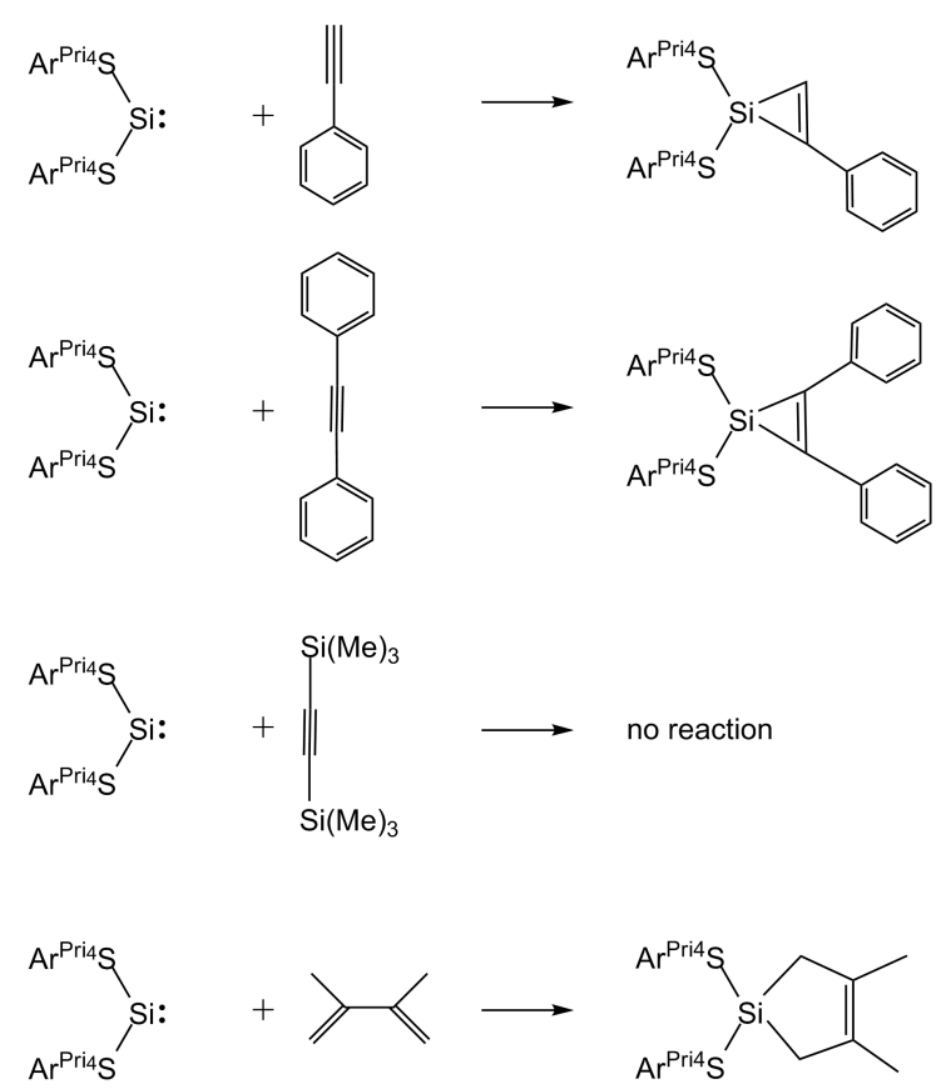

Scheme 1. Reactions of $\mathrm{Si}\left(\mathrm{SAr}^{i \mathrm{Pr}_{4}}\right)_{2}$ with phenylacetylene, diphenylacetylene, bis(trimethylsilyl)acetylene, and 2,3-dimethyl-butadiene.

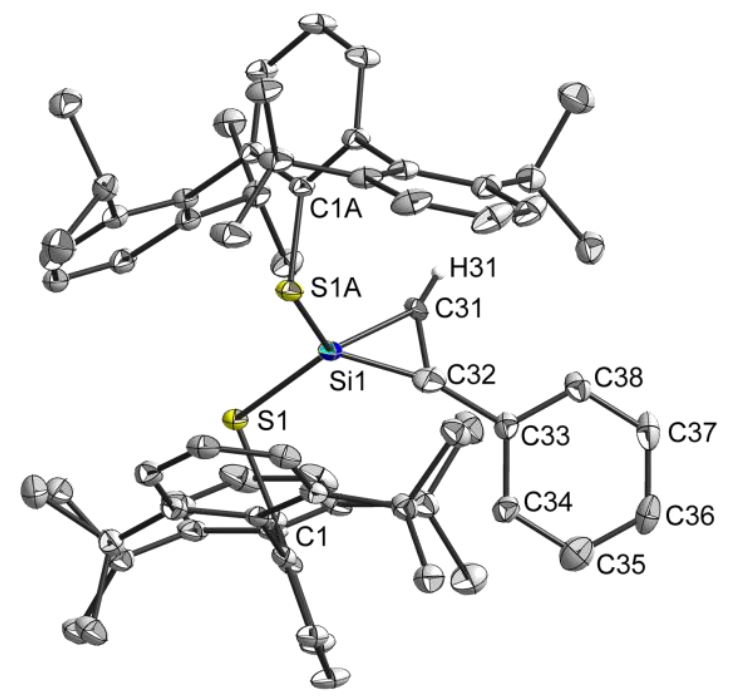

Figure 1. Thermal ellipsoid plot (30\%) of the molecular structure of $\mathbf{1}$. Hydrogen atoms (except H31), co-crystallized toluene molecule and disorder of the $\mathrm{C}(31)-\mathrm{C}(38)$ group are not shown. Selected bond distances $[\AA]$ and angles $\left[{ }^{\circ}\right]$ : Si1-C31 1.796(2), Si1-S1 
2.1264(6), S1-C1 1.8014(19), C31-C31 1.328(5), C31-C32 1.470(3); C31-Si1-C31 43.42(16), C31-C31-Si1 68.29(8), Si1-C31-C31, 68.29(8), S1-Si1-S1 111.08(4), C1-S1Sil 100.87(6), S1-Si1-C31, 118.700(1).

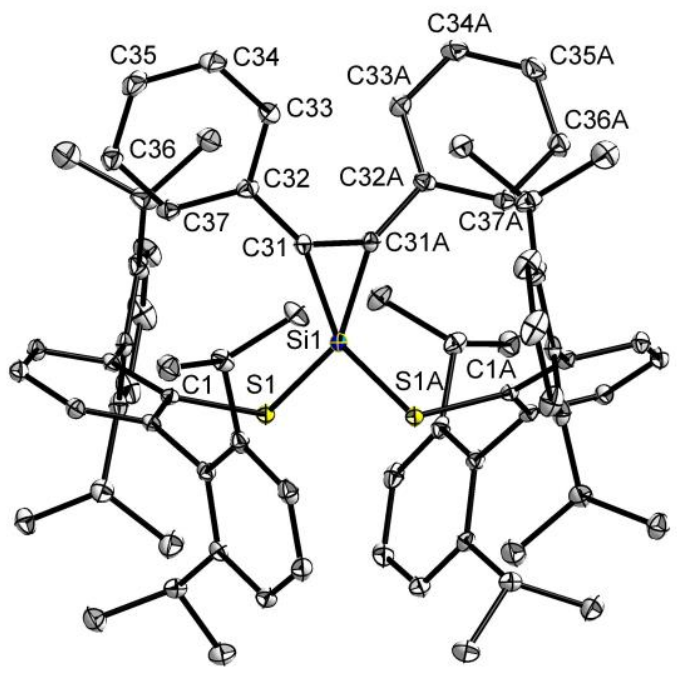

Figure 2. Thermal ellipsoid plot (30\%) of of the molecular structure of 2. Hydrogen atoms are not shown. Selected bond distances $[\AA]$ and angles $\left[{ }^{\circ}\right]$ : Si1-C31 1.8158(13), Si1-S1 2.1398(4); S1-C1 1.7955(12), C31-C31 1.357(3), C31-C32 1.4690(17); C31Si1-C31 43.90(8), C31-C31-Si1 68.05(4), Si1-C31-C31 68.05(4), S1-Si1-S1 108.97(2), C1-S1-Si1 101.49(4), S1-Si1-C31 118.05(4). 


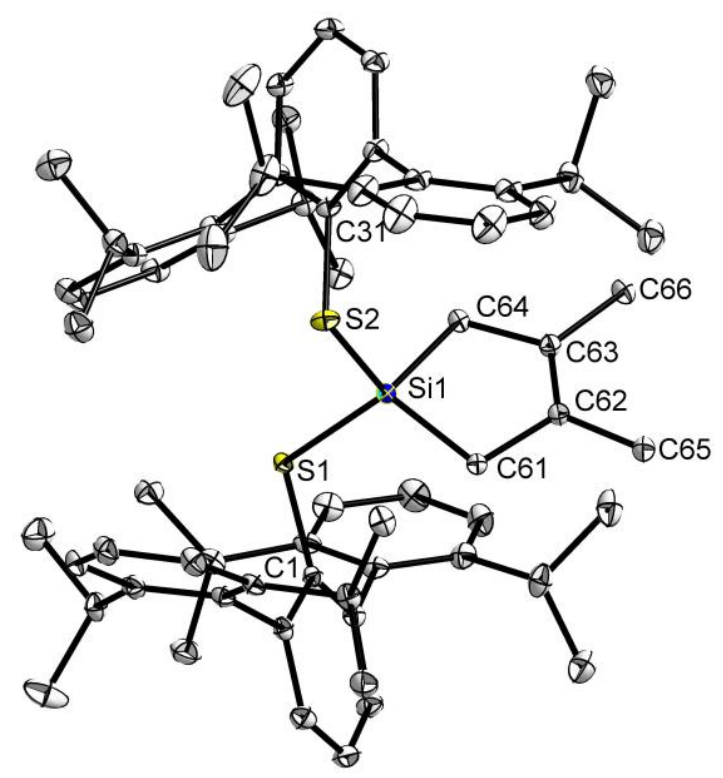

Figure 3. Thermal ellipsoid plot $(30 \%)$ of of the molecular structure of $\mathbf{3}$. Hydrogen atoms and co-crystallized toluene molecules are not shown. Selected bond distances [A] and angles $\left[{ }^{\circ}\right]$ : Si1-C61 1.8831(12), Si1-C64 1.8810(13); C61-C62 1.5249(17), C64-C63 1.5252(17), C62-C63 1.3340(19), C62-C65 1.5059(18), C63-C66 1.5036(18), Si1-S1 2.1495(4), Si1-S2 2.1456(5), S1-C1 1.7985(12), S2-C31 1.7885(13); C61-Si1-C64 96.08(5), Si1-C64-C63 102.31(8), Si1-C61-C62 102.47(8), C64-C63-C62 118.93(11), C61-C62-C63 118.49(11), S1-Si1-S2 106.337(18), C1-S1-Si1 106.44(4), C31-S2-Si1 106.70(4), S1-Si1-C61 114.89(4), S2-Si1-C64 110.93(4).

The compounds $\mathbf{1 - 3}$ were characterized by ${ }^{1} \mathrm{H},{ }^{13} \mathrm{C}\left\{{ }^{1} \mathrm{H}\right\}$, and ${ }^{29} \mathrm{Si} \mathrm{NMR}$ spectroscopy and by X-ray structural analysis. Compound $\mathbf{1}$ crystallizes in the centrosymmetric, orthorhombic space group Pccn. The $\mathrm{C}(31)-\mathrm{C}(38)$ group is found to exist at half occupancy in two orientations of which only one is shown in Figure 1. Compound $\mathbf{2}$ also crystallizes in the centrosymmetric, orthorhombic space group Pccn. The molecular structure exhibits a mirror plane of symmetry perpendicular to the silacyclopropene ring (Si1-C31-C31A). Compound 3, which crystallizes in the triclinic space group P1, has no required symmetry element. 
It can be seen that the ring $\mathrm{C}-\mathrm{C}$ distances in the highly strained compounds $\mathbf{1}$ $(1.328(5) \AA)$ and $2(1.357(3) \AA)$ and the C62-C63 distance $(1.3340(19) \AA)$ in the relatively unstrained compound $\mathbf{3}$ are in the typical range for carbon=carbon double bonds $(1.339 \AA \text { in ethylene })^{14}$ which is consistent with the assignment of $\mathbf{1}$ and $\mathbf{2}$ as silacyclopropenes and $\mathbf{3}$ as a silacyclopent-3-ene. The Si1-C31 distances in silirene $\mathbf{1}$ (1.796(2) $\AA$ ) are only slightly shorter than in the silirene 2 (1.8158(13) $\AA$ ). However, the C-Si-C, C-C-Si and Si-C-C angles in $1\left(43.42(16)\right.$ and 68.29(8) $\left.{ }^{\circ}\right)$ and $2(43.90(8)$ and $\left.68.05(4)^{\circ}\right)$ not significantly different.

The bond distances and bond angles for silacycloropene rings in $\mathbf{1}$ and $\mathbf{2}$ are in the typical range (Si-C 1.737(4)-1.888(4); C=C 1.276(8)-1.371(2), C-Si-C 39.9(2)-45.4(2), C-C-Si 66.7(3)-71.7(3)). ${ }^{10,} 15$ The cycloaddition of alkynes to the silylene $\mathrm{Si}\left(\mathrm{SAr}^{i \mathrm{Pr}_{4}}\right)_{2}$ results in four-coordinate silicon geometries with interligand and ring angles in the range of $43.42(16)$ to $111.08(4)^{\circ}$ for $\mathbf{1}$ and $43.90(8)$ to $118.05(4)^{\circ}$ for $\mathbf{2}$. The S1-Si1-S1 angles in $\mathbf{1}$ and 2 are $26^{\circ}$ and $24^{\circ}$ wider than that in the precursor silylene $\left(85.08(5)^{\circ}\right) .{ }^{12}$ The cyclization results in shortened Si1-S1 distances (Si1-S1 2.1264(6)) and longer C-S1 distances $\mathrm{S} 1-\mathrm{C} 1 \mathrm{1.8014}(19)$ for $\mathbf{1}$ and has little effect on the Si1-S1 distance in $\mathbf{2}$ (Si1-S1 2.1398(4)) in comparison to those in the precursor silylene (2.137(1) and 1.775(2) ̊̊ for Si1-S1 and S1-C1 bonds, respectively).

In compound 3, the silicon carbon distances of the silacycle Si1-C61 and Si1-C64 (1.8831(12) and 1.8810(13) ̊) are longer than the silicon carbon distances in silacyclopent-3-enes of Driess which were obtained by the reaction of the ylide-like $\mathrm{N}$ heterocyclic silylene :SiL $\left.\left\{\mathrm{L}=\mathrm{CH}\left[\left(\mathrm{C}=\mathrm{CH}_{2}\right) \mathrm{CMe}\right][\mathrm{N}(\mathrm{Ar})]_{2}\right], \mathrm{Ar}=2,6-i \mathrm{Pr}_{2} \mathrm{C}_{6} \mathrm{H}_{3}\right\}$ with 2,3dimethyl-1,3-butadiene. ${ }^{16}$ They are, however, shorter than in the silacyclopent-3-enes of 
West using the ylid-like silylene $N, N$ '-di-tert-butyl-1,3-diaza-2-sila-2-ylidene, ${ }^{17}$ and in the same range as the silicon carbon distances in West's silacyclopent-3-enes obtained by the reaction of a silole dianion with 2,3-dimethyl-1,3-butadiene. ${ }^{18}$ The interligand and ring angles of the four-coordinate silicon atom in $\mathbf{3}$ are in the range of 96.08(5) to $114.89(4)^{\circ}$. The S1-Si1-S2 $\left(106.337(18)^{\circ}\right)$ angle in 3 is $21^{\circ}$ wider than that in the precursor silylene $\left(85.08(5)^{\circ}\right) .^{12}$

The ${ }^{29} \mathrm{Si}$ NMR spectra of $\mathbf{1 - 3}$ were recorded in $d^{8}$-toluene. For $\mathbf{1}$, an upfield signal at $-70.6 \mathrm{ppm}$ which displays coupling to $\mathrm{H} 31\left({ }^{2} J\left({ }^{29} \mathrm{Si}-{ }^{1} \mathrm{H}\right)=5.1 \mathrm{~Hz}\right)$ was observed. For compound 2 a singlet at $-72.8 \mathrm{ppm}$ was found. Both resonances are in the more downfield region of the chemical shift range for silirene compounds (from -63.3 to $-152.3 \mathrm{ppm}),{ }^{10,15}$ and they are shifted further downfield than chemical shifts observed for Driess's silirene compounds $\mathrm{LSiC}(\mathrm{H}) \mathrm{C}(\mathrm{Ph})(-86.4 \mathrm{ppm})$ and $\mathrm{LSiC}(\mathrm{Ph}) \mathrm{C}(\mathrm{Ph}) \quad(-89.2$ ppm) $\left\{\mathrm{L}=\mathrm{CH}\left[\left(\mathrm{C}=\mathrm{CH}_{2}\right) \mathrm{CMe}\right][\mathrm{N}(\operatorname{aryl})]_{2}\right.$; aryl $\left.\left.=2,6-i \mathrm{Pr}_{2} \mathrm{C}_{6} \mathrm{H}_{3}\right)\right\}$ in $d^{6}$-benzene. ${ }^{15 \mathrm{~d}}$ This is despite of the fact that sulfur is less electronegative than nitrogen, ${ }^{19}$ which would normally be expected to result in an upfield shift. The ${ }^{1} \mathrm{H}$ NMR spectrum of $\mathbf{1}$ revealed a signal at $8.11 \mathrm{ppm}$ in $d^{8}$-toluene for the alkenic proton of the silirene ring that is shifted more downfield than Driess's silirene $\mathrm{LSiC}(\mathrm{H}) \mathrm{C}(\mathrm{Ph})(7.86 \mathrm{ppm}) .{ }^{15 \mathrm{~d}}$ For 3, the ${ }^{29} \mathrm{Si}$ NMR spectrum revealed a downfield signal at $31.49 \mathrm{ppm}$ which displayed a 1:4:6:4:1 intensity quintet pattern owing to coupling to the hydrogen atoms of the methylene groups in the silacyclopent-3-ene. The ${ }^{2} J(29 \mathrm{Si}-1 \mathrm{H})$ coupling constant is $5.82 \mathrm{~Hz}$. Other silacyclo-pent3 -enes exhibits similar ${ }^{29} \mathrm{Si}$ chemical shifts in this region. For instance, the silacyclopent3-ene synthesized by Kira with the dialkylsilylene (2,2,5,5tetrakis(trimethylsilyl)silacyclopentan-1,1-diyl) shows a signal at $33.4 \mathrm{ppm} .{ }^{10}$ 
The silylene $\mathrm{Si}\left(\mathrm{SAr}^{i \mathrm{Pr}_{4}}\right)_{2}$ did not react with the alkenes such as propene, Z-2butene, tert-butyl ethylene, cyclopentene, or 1-hexene, which we tentatively ascribe to the more sterically hindered nature of the silylene $\mathrm{Si}\left(\mathrm{SAr}^{i \mathrm{Pr}_{4}}\right)_{2}$.

We were also interested to see if the germylene $\mathrm{Ge}\left(\mathrm{SAr}^{\mathrm{Me}_{6}}\right)_{2}$ and the stannylene $\mathrm{Sn}\left(\mathrm{SAr}^{\mathrm{Me}_{6}}\right)_{2}$ reacted with ethylene in a similar manner as with $\mathrm{Si}\left(\mathrm{SAr}^{i \mathrm{Pr}_{4}}\right)_{2}$. However, no reaction was observed for the $\mathrm{Ge}$ and $\mathrm{Sn}$ analogues under similar reaction conditions. In order to understand why the reactivity of the heavier tetrylenes differs from those of their Si analogues, a series of DFT calculations was carried out for model systems $\mathrm{E}(\mathrm{SPh})_{2}(\mathrm{E}$ $=\mathrm{Ge}, \mathrm{Sn})$. This simplified structure was used in our earlier study of electronic structure and reactivity of the silylene $\mathrm{Si}(\mathrm{SPh})_{2}$ with ethylene, reproducing the experimentally deduced energies in good precision. ${ }^{13}$

The energies of the investigated reactions are summarized in Figure 4 along with those corresponding to the formation of the silirane $(\mathrm{PhS})_{2} \mathrm{SiCH}_{2} \mathrm{CH}_{2} \cdot{ }^{13}$ In all cases, the cycloaddition proceeds via single transition state with an activation barrier of 79 and 171 $\mathrm{kJ} \mathrm{mol}^{-1}$ (Gibbs energies with the zero level set at reactants) for $(\mathrm{PhS})_{2} \mathrm{GeCH}_{2} \mathrm{CH}_{2}$ and $(\mathrm{PhS})_{2} \mathrm{SnCH}_{2} \mathrm{CH}_{2}$, respectively. The relative energies of the products are 69 and $162 \mathrm{~kJ}$ $\mathrm{mol}^{-1}$, which shows that the reaction is energetically unfavorable for both $\mathrm{Ge}(\mathrm{SPh})_{2}$ and $\mathrm{Sn}(\mathrm{SPh})_{2}$ and that the products lie at very shallow local minimum (ca. $\left.10 \mathrm{~kJ} \mathrm{~mol}^{-1}\right)$. The geometries of the transition states leading to $(\mathrm{PhS})_{2} \mathrm{GeCH}_{2} \mathrm{CH}_{2}$ and $(\mathrm{PhS})_{2} \mathrm{SnCH}_{2} \mathrm{CH}_{2}$ are very similar to the geometries of the reaction products (late transition state) with one of the ethylene carbon atoms only slightly distorted from its equilibrium position (Figure 4). These structural features are in stark contrast to the transition state of the silirane 
$(\mathrm{PhS})_{2} \mathrm{SiCH}_{2} \mathrm{CH}_{2}$ in which the distance between the $\mathrm{Si}$ atom and ethylene is significantly longer (early transition state). ${ }^{13}$
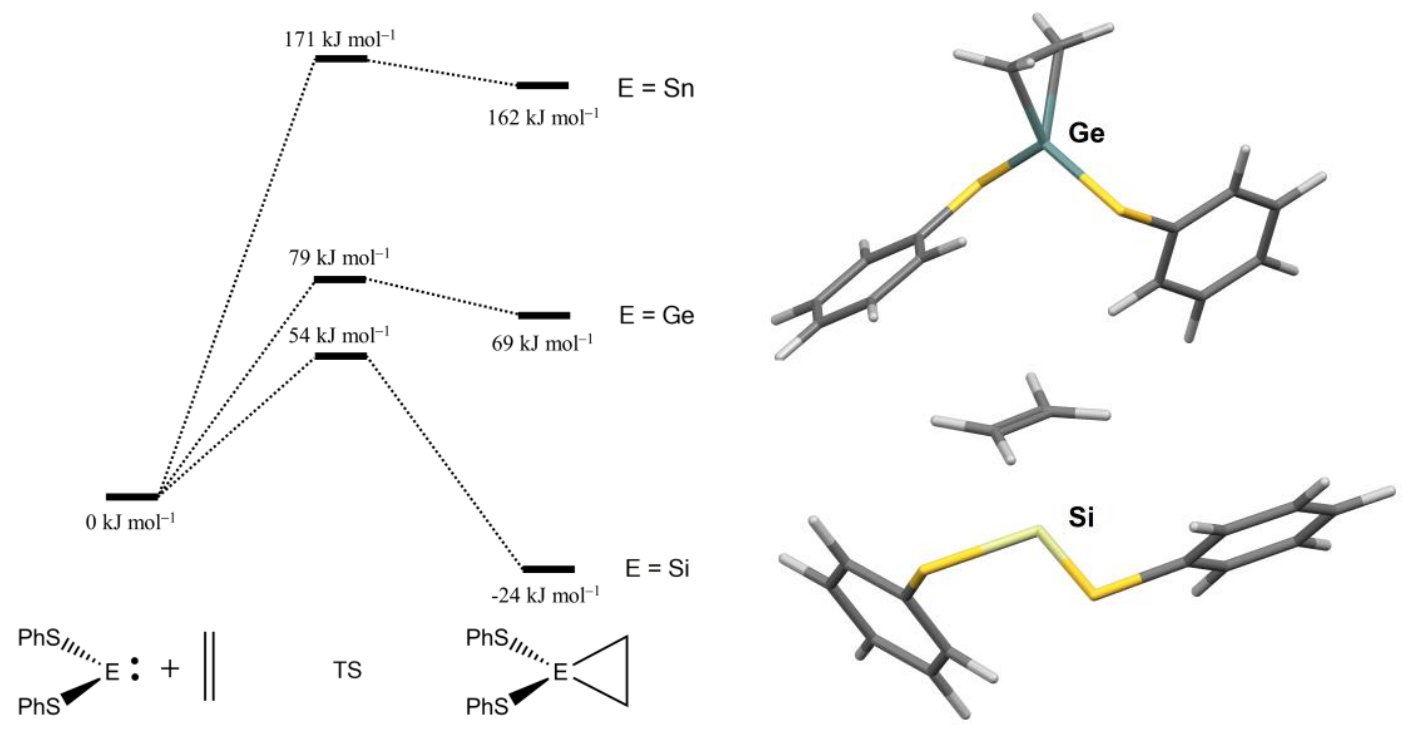

Figure 4. Gibbs energy diagram for the reactions of $\mathrm{E}(\mathrm{SPh})_{2}(\mathrm{E}=\mathrm{Si}, \mathrm{Ge}, \mathrm{Sn})$ with ethylene to give $(\mathrm{PhS})_{2} \mathrm{ECH}_{2} \mathrm{CH}_{2}$ via corresponding transition states (TS). Optimized geometries of the TSs are shown on the right for $\mathrm{E}=\mathrm{Si}$ and $\mathrm{Ge}$.

The Ziegler-Rauk-Morokuma energy decomposition analysis (EDA) gives an instantaneous interaction energy of -227 and $-151 \mathrm{~kJ} \mathrm{~mol}^{-1}$ for the Ge and $\mathrm{Sn}$ products, respectively; the value for the corresponding silirane is $-296 \mathrm{~kJ} \mathrm{~mol}^{-1}$. ${ }^{13}$ An analysis of the components of the instantaneous interaction energy (Pauli repulsion, electrostatic interaction, and orbital interaction) shows that when descending group 14, the orbital interaction becomes less favorable for bonding and at a significantly faster rate than what can be offset by the sum of Pauli repulsion and electrostatic interactions. ${ }^{20}$ Thus, the mixing of silylene and ethylene orbitals upon silirane formation can efficiently 
counterbalance the repulsive energy components, leading to a stronger interaction than in the case of its germanium and tin analogues.

It should be noted that the instantaneous interaction energy between $\mathrm{E}(\mathrm{SPh})_{2}$ and ethylene is negative for all elements $\mathrm{E}$, whereas the overall reaction energy is negative only for $\mathrm{E}=\mathrm{Si}$. The differences in the calculated energies are due to the distortion energy, i.e. the energy required to distort the interactive fragments to the geometry they have in the product, which becomes more positive for the heavier tetrels germanium and tin. Thus, it is only in the case of the silirane $(\mathrm{PhS})_{2} \mathrm{SiCH}_{2} \mathrm{CH}_{2}$ when the distortion energy is small enough that it does not completely negate the favorable bonding interactions between the tetrylene and ethylene. As a whole, the computational results are in agreement with the notion that, while going down the group 14, the lone pair at the tetrel center becomes more inert and the $\mathrm{E}-\mathrm{C}$ bond energies decrease. The energy gain from the formation of two $\mathrm{Ge}-\mathrm{C}$ and $\mathrm{Sn}-\mathrm{C}$ bonds is simply not enough to overcome the energy required to break a $\mathrm{C}=\mathrm{C}$ double bond and form the pseudo-tetrahedral bonding arrangement around the tetrel center.

After investigating the energetics of the reaction of ethylene with the heavier tetrylenes, the reaction of silylene $\mathrm{Si}(\mathrm{SPh})_{2}$ with the simplest alkyne, acetylene, was modelled for comparison (Figure 5). The results show that the cycloaddition proceeds via single transition state with an activation barrier of $54 \mathrm{~mol}^{-1}$ (Gibbs energy with the zero level set at reactants); the relative energy of the product is $-75 \mathrm{~kJ} \mathrm{~mol}^{-1}$. Thus, the reaction is expected to be facile, as it is, and not reversible because the barrier from the product back to the reactants is $129 \mathrm{~kJ} \mathrm{~mol}^{-1}$. 


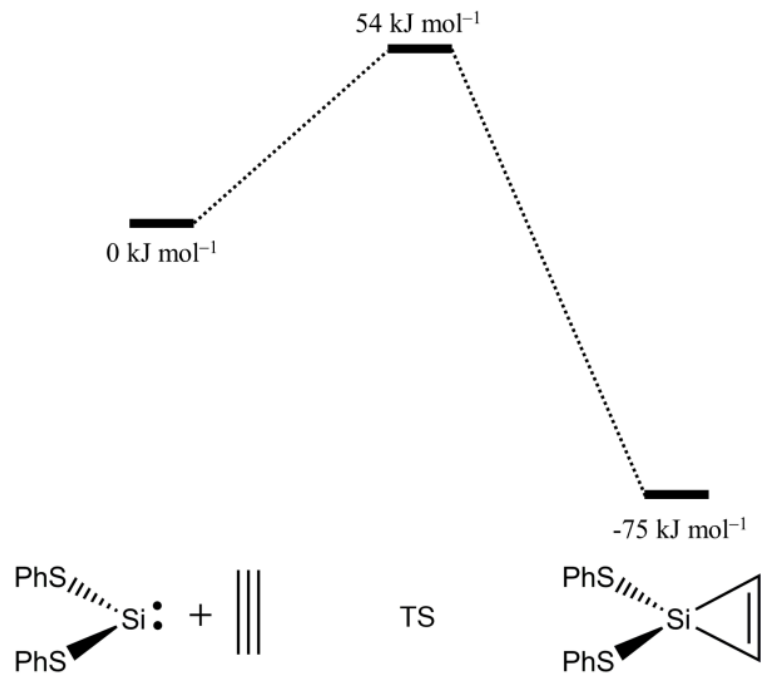

Figure 5. Gibbs energy diagram for the reaction of $\mathrm{Si}(\mathrm{SPh})_{2}$ with acetylene to give $(\mathrm{PhS})_{2} \mathrm{SiCHCH}$ via corresponding transition state (TS).

\section{CONCLUSION}

In conclusion, three- and five-membered silicon heterocycles can be easily accessed at ambient conditions by the reaction of the acyclic silylene $\mathrm{Si}\left(\mathrm{SAr}^{i \mathrm{Pr}_{4}}\right)_{2}$ with the alkynes phenylacetylene and diphenylacetylene, and the diene 2,3-dimethyl-1,3-butadiene, yielding silacyclopropenes and a silacyclopentene, respectively. For the reactions of the germylenes and stannylenes $\mathrm{E}\left(\mathrm{SAr}^{\mathrm{Me}_{6}}\right)_{2}(\mathrm{E}=\mathrm{Ge}, \mathrm{Sn})$ with ethylene, the results of computational studies suggest that the $\mathrm{E}-\mathrm{C}$ bonding interactions in the products $\left(\mathrm{Ar}^{\mathrm{Me}_{6}} \mathrm{~S}\right)_{2} \mathrm{ECH}_{2} \mathrm{CH}_{2}$ are not able to overcome the energy required to distort the geometries of the fragments in order for the reaction to take place. Even the silirane product $\left(\mathrm{Ar}^{\mathrm{Me}_{6}} \mathrm{~S}\right)_{2} \mathrm{SiCH}_{2} \mathrm{CH}_{2}$ is already fairly loosely bound, as evident from the reversible reaction observed experimentally and predicted computationally for $(\mathrm{PhS})_{2} \mathrm{SiCH}_{2} \mathrm{CH}_{2}$. 


\section{EXPERIMENTAL DETAILS}

All reactions were performed with the use of modified Schlenk techniques with additional manipulations using a Vacuum Atmospheres OMNI-Lab drybox. All solvents were dried over an alumina column, followed by storage over a potassium mirror, and degassed three times (freeze-pump-thaw) prior to use. $\operatorname{Si}\left(\mathrm{SAr}^{i \mathrm{Pr}_{4}}\right)_{2}\left(\mathrm{Ar}^{i \mathrm{Pr}_{4}}=\mathrm{C}_{6} \mathrm{H}_{3}-\right.$ 2,6 $\left.6\left(\mathrm{C}_{6} \mathrm{H}_{3}-2,6-i \mathrm{Pr}_{2}\right)_{2}\right)$ was prepared according to a literature procedures. ${ }^{1}$ Phenylacetylene was dried with molecular sieves and vacuum distilled prior to use. 2,3-Dimethyl-1,3butadiene was dried with $\mathrm{CaH}_{2}$ and distilled under $\mathrm{N}_{2}$ prior to use. Diphenylacetylene was dried in vacuum for 4 hours.

${ }^{1} \mathrm{H},{ }^{13} \mathrm{C}$, and ${ }^{29} \mathrm{Si}$ NMR data were obtained on a Varian Inova $600 \mathrm{MHz}$ spectrometer. The ${ }^{1} \mathrm{H}$ and ${ }^{13} \mathrm{C}$ NMR spectra were referenced to $\mathrm{d}^{8}$-toluene and/or trace silicone grease $\left(\delta=0.26 \mathrm{ppm}\right.$ in $\left.\mathrm{C}_{7} \mathrm{D}_{8}\right)$. The ${ }^{29} \mathrm{Si}$ NMR spectra were referenced to an external standard of tetramethlysilane (TMS) $(\delta=0 \mathrm{ppm})$. IR spectra were recorded as Nujol mulls between CsI plates on a Perkin-Elmer 1430 spectrophotometer. Melting points were measured in glass capillaries sealed under $\mathrm{N}_{2}$ by using a Mel-Temp II apparatus and are uncorrected.

$\left(\operatorname{Ar}^{i \mathrm{Pr}_{4}} \mathbf{S}\right)_{2} \operatorname{SiC}(\mathbf{H})=\mathbf{C}(\mathbf{P h})$ (1) 1.5PhMe. A yellow solution of $\operatorname{Si}\left(\mathrm{SAr}^{i \mathrm{Pr}_{4}}\right)_{2}(0.532 \mathrm{~g}, 0.6$ mmol) in toluene (ca. $30 \mathrm{~mL})$ was treated with phenylacetylene $(0.39 \mathrm{~mL}, 3.6 \mathrm{mmol})$ via syringe. The yellow solution became colorless within a few minutes. Stirring was continued for $24 \mathrm{~h}$ to ensure complete reaction, after which time the solution was filtered by filter-tipped cannula and concentrated to ca. $6 \mathrm{~mL}$. Storage of the solution at ca. $7{ }^{\circ} \mathrm{C}$ afforded colorless block-like crystals of the product $1 \cdot 1.5 \mathrm{PhMe}(0.135 \mathrm{~g}, 0.0136 \mathrm{mmol}$, 
$23 \%$ ) after two days. M. p. $203-205{ }^{\circ} \mathrm{C}$ (bound phenylacetylene is released under formation of a yellow compound). ${ }^{1} \mathrm{H}$ NMR $\left(599.7 \mathrm{MHz}, d^{8}\right.$-toluene, $\left.295 \mathrm{~K}\right) \delta=0.91(\mathrm{~d}$, $\left.12 \mathrm{H}, \mathrm{CH}_{3}, o-\mathrm{CH}\left(\mathrm{CH}_{3}\right)_{2},{ }^{3} \mathrm{~J}_{\mathrm{H}, \mathrm{H}}=6.57 \mathrm{~Hz}\right), 0.98\left(\mathrm{~d}, 12 \mathrm{H}, \mathrm{CH}_{3}, o-\mathrm{CH}\left(\mathrm{CH}_{3}\right)_{2},{ }^{3} \mathrm{~J}_{\mathrm{H}, \mathrm{H}}=6.74\right.$ $\mathrm{Hz}$ ), 1.04 (s, broad, $\left.24 \mathrm{H}, \mathrm{CH}_{3}, o-\mathrm{CH}\left(\mathrm{CH}_{3}\right)_{2}\right), 2.11$ (s, $\mathrm{CH}_{3}$-toluene), 2.47 (multiplet, broad, $4 \mathrm{H}, \mathrm{CH}, o-\mathrm{CH}\left(\mathrm{CH}_{3}\right)_{2}$ ), 2.53 (multiplet, broad, $\left.4 \mathrm{H}, \mathrm{CH}, o-\mathrm{CH}\left(\mathrm{CH}_{3}\right)_{2}\right) 6.69-6.70$ (multiplet, 1H, Ph-ring of silirene ring), 6.95-6.97 (multiplet, 2H, Ph-ring of silirene ring), 6.96-7.01 (m, toluene), $7.04\left(\mathrm{t}, 2 \mathrm{H}, p-\mathrm{C}_{6} \mathrm{H}_{3},{ }^{3} \mathrm{~J}_{\mathrm{H}, \mathrm{H}}=7.56 \mathrm{~Hz}\right), 7.05(\mathrm{~d}, 2 \mathrm{H}, \mathrm{CH}(2,6)$ Ph-ring of silirene, $\left.{ }^{3} \mathrm{~J}_{\mathrm{H}, \mathrm{H}}=7.61 \mathrm{~Hz}\right), 7.06\left(\mathrm{~d}, 4 \mathrm{H}, m-\mathrm{C}_{6} \mathrm{H}_{3},{ }^{3} \mathrm{~J}_{\mathrm{H}, \mathrm{H}}=7.85 \mathrm{~Hz}\right), 7.09(\mathrm{~s}$, toluene), $7.13\left(\mathrm{~d}, 8 \mathrm{H}, m-\mathrm{C}_{6} \mathrm{H}_{3}-2,6-i \mathrm{Pr}_{2},{ }^{3} \mathrm{~J}_{\mathrm{H}, \mathrm{H}}=7.53 \mathrm{~Hz}\right), 7.25\left(\mathrm{t}, 4 \mathrm{H}, p-\mathrm{C}_{6} \mathrm{H}_{3}-2,6-i \mathrm{Pr}_{2}\right.$, ${ }^{3} \mathrm{~J}_{\mathrm{H}, \mathrm{H}}=7.72 \mathrm{~Hz}$ ), 8.11 (s, $1 \mathrm{H}, \mathrm{H}$-atom of silirene ring). ${ }^{13} \mathrm{C}\left\{{ }^{1} \mathrm{H}\right\}$ NMR ( $d^{8}$-toluene, 150.8 $\mathrm{MHz}, 295 \mathrm{~K}): \delta=23.17\left(o-\mathrm{CH}\left(\mathrm{CH}_{3}\right)_{2}\right), 23.62\left(o-\mathrm{CH}\left(\mathrm{CH}_{3}\right)_{2}\right), 26.15\left(o-\mathrm{CH}\left(\mathrm{CH}_{3}\right)_{2}\right), 26.24$ $\left(o-\mathrm{CH}\left(\mathrm{CH}_{3}\right)_{2}\right), 30.88 \quad\left(o-\mathrm{CH}\left(\mathrm{CH}_{3}\right)_{2}\right), 31.01 \quad\left(o-\mathrm{CH}\left(\mathrm{CH}_{3}\right)_{2}\right), \quad 123.37, \quad 125.63,126.34$, $127.57,128.23,128.42,128.47,128.61,128.70,128.78,129.17,129.29,129.32,131.34$, $132.35,133.88,134.78,137.95,139.35,146.33,146.48,151.27$ ( $\mathrm{Si}-\mathrm{C}=C-\mathrm{Ph}$ in silirene), $172.13\left(\mathrm{Si}-\mathrm{C}=C-\mathrm{Ph}\right.$ in silirene). ${ }^{29} \mathrm{Si} \mathrm{NMR}\left(119.1 \mathrm{MHz}, d^{8}\right.$-toluene, $\left.295 \mathrm{~K}\right): \delta=-70.64$ ppm (doublet, ${ }^{2} \mathrm{~J}_{\mathrm{Si}-\mathrm{H}}=5.14 \mathrm{~Hz},\left(\mathrm{Si}-\mathrm{CH}=\mathrm{CPh}\right.$ ). IR (nujol, CsI plates, $\mathrm{cm}^{-1}$ ): 3295 (weak, sharp), 3030 (weak, sharp), 2697 (weak, medium), 1930 (weak, broad), 1860 (weak, broad), 1798 (weak, broad), 1760 (weak, broad), 1650 (weak, broad), 1580 (medium, sharp), 1560 (strong, sharp), 1550 (medium, sharp), 1445 (strong, broad), 1370 (strong, sharp), 1350 (strong, sharp), 1310 (medium, sharp), 1238 (medium, sharp), 1165 (medium, sharp), 1145 (weak, sharp), 1088 (medium, broad), 1070 (medium, sharp), 1050 (strong, sharp), 1030 (strong, sharp), 1016 (strong, sharp), 928 (medium, sharp), 914 (weak, sharp), 875 (medium, sharp), 814 (strong, sharp), 800 (strong, sharp), 785 
(strong, sharp), 745 (strong, broad), 724 (medium, sharp), 690 (medium, sharp), 575 (weak, sharp), 550 (strong, sharp), 514 (medium, sharp), 497 (medium, sharp), 460 (medium, medium), 420 (weak, medium), 385 (medium, medium), 355 (weak, medium), 328 (weak, medium), 240 (medium, sharp), 220 (weak, sharp), 205 (medium, sharp).

$\left(\mathbf{A r}{ }^{i \mathbf{P r}_{4}} \mathbf{S}\right)_{2} \mathbf{S i C}(\mathbf{P h})=\mathbf{C}(\mathbf{P h})(2)$. A solution of diphenylacetylene $\left.0.107 \mathrm{~g}, 0.6 \mathrm{mmol}\right)$ in toluene (ca. $20 \mathrm{~mL}$ ) was added dropwise to a yellow solution of $\operatorname{Si}\left(\operatorname{SAr}^{i \mathrm{Pr}_{4}}\right)_{2}(0.532 \mathrm{~g}, 0.6$ mmol) in toluene (ca. $30 \mathrm{~mL}$ ). The yellow solution became colorless within two days, after which time the solution was filtered by filter-tipped cannula and concentrated to ca. $7 \mathrm{~mL}$. Storage of the solution at ca. $7{ }^{\circ} \mathrm{C}$ afforded colorless block-like crystals of the product $2(0.320 \mathrm{~g}, 0.03 \mathrm{mmol}, 50 \%)$ after two days. M. p. at $250{ }^{\circ} \mathrm{C}$ the compound begins to turn yellow. ${ }^{1} \mathrm{H}$ NMR $\left(599.7 \mathrm{MHz}, d^{6}\right.$-benzene, $\left.295 \mathrm{~K}\right) \delta=0.95\left(\mathrm{~d}, 24 \mathrm{H}, \mathrm{CH}_{3}\right.$, $o-\mathrm{CH}\left(\mathrm{CH}_{3}\right)_{2},{ }^{3} \mathrm{~J}_{\mathrm{H}, \mathrm{H}}=5.94 \mathrm{~Hz}$ ), 1.42 (s, broad, $\left.24 \mathrm{H}, \mathrm{CH}_{3}, o-\mathrm{CH}\left(\mathrm{CH}_{3}\right)_{2}\right), 2.54$ (multiplet, broad, 4H, $\left.\mathrm{CH}, o-\mathrm{CH}\left(\mathrm{CH}_{3}\right)_{2}\right)$, 6.86-6.87 (multiplet, broad, 3H, $\mathrm{CH}(3,4,5) \mathrm{Ph}$-ring of silirene ring), 6.95-6.97 (multiplet, 2H, $\mathrm{CH}(2,6) \mathrm{Ph}-$ ring of silirene, $\left.4 \mathrm{H}, m-\mathrm{C}_{6} \mathrm{H}_{3}\right), 7.05$ (t, $\left.2 \mathrm{H}, p-\mathrm{C}_{6} \mathrm{H}_{3},{ }^{3} \mathrm{~J}_{\mathrm{H}, \mathrm{H}}=7.58 \mathrm{~Hz}\right), 7.21\left(\mathrm{~d}, 8 \mathrm{H}, m-\mathrm{C}_{6} \mathrm{H}_{3}-2,6-i \mathrm{Pr}_{2},{ }^{3} \mathrm{~J}_{\mathrm{H}, \mathrm{H}}=7.51 \mathrm{~Hz}\right), 7.30(\mathrm{t}, 4 \mathrm{H}$, $\left.p-\mathrm{C}_{6} \mathrm{H}_{3}-2,6-i \mathrm{Pr}_{2},{ }^{3} \mathrm{~J}_{\mathrm{H}, \mathrm{H}}=7.73 \mathrm{~Hz}\right) .{ }^{13} \mathrm{C}\left\{{ }^{1} \mathrm{H}\right\}$ NMR: could not be obtained due to the low solubility of 2 in $d^{8}$-toluene and $d^{6}$-benzene. ${ }^{29} \mathrm{Si}$ NMR (119.1 MHz, $d^{8}$-toluene, $\left.295 \mathrm{~K}\right)$ : - 72.83 ppm, singlet. IR (nujol, CsI plates, $\mathrm{cm}^{-1}$ ): 3040 (strong, medium), 2705 (weak, medium), 1940 (weak, broad), 1862 (weak, sharp), 1810 (weak, sharp), 1700 (weak, sharp), 1595 (weak, sharp), 1575 (medium, sharp), 1558 (medium, sharp), 1495 (medium, sharp), 1455 (strong, broad), 1380 (strong, sharp), 1360 (strong, sharp), 1320 (medium, sharp), 1295 (weak, sharp), 1252 (medium, sharp), 1180 (medium, sharp), 
1155 (weak, sharp), 1102 (weak, sharp), 1094 (weak, sharp), 1072 (weak, sharp), 1058 (medium, sharp), 1036 (medium, sharp), 850 (medium, sharp), 820 (medium, sharp), 805 (strong, sharp), 790 (strong, sharp), 755 (strong, broad), 728 (weak, sharp), 710 (strong, sharp), 698 (strong, sharp), 542 (medium, sharp), 490 (medium, sharp).

$\left(\mathrm{Ar}^{i \mathrm{Pr}_{4}} \mathrm{~S}\right)_{2} \mathrm{SiCH}_{2} \mathrm{C}(\mathrm{Me}) \mathrm{C}(\mathrm{Me}) \mathrm{CH}_{2}$ (3) 1.5PhMe. A yellow solution of $\mathrm{Si}\left(\mathrm{SAr}^{i \mathrm{Pr}_{4}}\right)_{2}(0.444$ g, $0.5 \mathrm{mmol}$ ) in toluene (ca. $30 \mathrm{~mL})$ was treated with 2,3-dimethyl-1,3-butadiene $(0.39$ $\mathrm{mL}, 5 \mathrm{mmol}$ ) via syringe. The yellow solution became colorless upon stirring for two days, after which time it was filtered with a filter-tipped cannula and concentrated to ca. 6 $\mathrm{mL}$. Storage of the solution at ca. $7{ }^{\circ} \mathrm{C}$ afforded colorless block-like crystals of 3·1.5PhMe $(0.220 \mathrm{~g}, 0.0227 \mathrm{mmol}, 45 \%)$ after one day. M. p. $243-245{ }^{\circ} \mathrm{C} .{ }^{1} \mathrm{H}$ NMR (599.7 MHz, d $d^{8}$-toluene, $\left.295 \mathrm{~K}\right): \delta=0.99\left(\mathrm{~d}, 24 \mathrm{H}, \mathrm{CH}_{3}, o-\mathrm{CH}\left(\mathrm{CH}_{3}\right)_{2},{ }^{3} \mathrm{~J}_{\mathrm{H}, \mathrm{H}}=6.78 \mathrm{~Hz}\right)$, $1.18\left(\mathrm{~d}, 24 \mathrm{H}, \mathrm{CH}_{3}, o-\mathrm{CH}\left(\mathrm{CH}_{3}\right)_{2},{ }^{3} \mathrm{~J}_{\mathrm{H}, \mathrm{H}}=6.82 \mathrm{~Hz}\right), 1.11$ (s, 4H, $\mathrm{CH}_{2}$, silacyclopentene), 1.40 (s, 6H, $\mathrm{CH}_{3}$, silacyclopentene), 2.53 (sept, 8H, $\mathrm{CH}, o-\mathrm{CH}\left(\mathrm{CH}_{3}\right)_{2},{ }^{3} \mathrm{~J}_{\mathrm{H}, \mathrm{H}}=6.70 \mathrm{~Hz}$ ), $6.97\left(\mathrm{t}, 2 \mathrm{H}, p-\mathrm{C}_{6} \mathrm{H}_{3},{ }^{3} \mathrm{~J}_{\mathrm{H}, \mathrm{H}}=7.53 \mathrm{~Hz}\right), 7.10\left(\mathrm{~d}, 4 \mathrm{H}, m-\mathrm{C}_{6} \mathrm{H}_{3},{ }^{3} \mathrm{~J}_{\mathrm{H}, \mathrm{H}}=7.56 \mathrm{~Hz}\right), 7.12(\mathrm{~d}, 8 \mathrm{H}$, $\left.m-\mathrm{C}_{6} \mathrm{H}_{3}-2,6-i \mathrm{Pr}_{2},{ }^{3} \mathrm{~J}_{\mathrm{H}, \mathrm{H}}=7.73 \mathrm{~Hz}\right), 7.25\left(\mathrm{t}, 4 \mathrm{H}, p-\mathrm{C}_{6} \mathrm{H}_{3}-2,6-i \mathrm{Pr}_{2},{ }^{3} \mathrm{~J}_{\mathrm{H}, \mathrm{H}}=7.71 \mathrm{~Hz}\right) .{ }^{13} \mathrm{C}\left\{{ }^{1} \mathrm{H}\right\}$ NMR $\left(d^{8}\right.$-toluene, $\left.150.8 \mathrm{MHz}, 295 \mathrm{~K}\right): \delta=19.78\left(\mathrm{CH}_{3}\right.$, silacyclopentene), 23.67 (o$\left.\mathrm{CH}\left(\mathrm{CH}_{3}\right)_{2}\right), 26.49\left(o-\mathrm{CH}\left(\mathrm{CH}_{3}\right)_{2}\right), 28.30\left(\mathrm{CH}_{2}\right.$, silacyclopentene $), 31.04\left(o-\mathrm{CH}\left(\mathrm{CH}_{3}\right)_{2}\right)$, $123.18\left(m-\mathrm{C}_{6} \mathrm{H}_{3}-2,6-i \mathrm{Pr}_{2}\right), 125.99\left(p-\mathrm{C}_{6} \mathrm{H}_{3}\right), 128.39\left(m-\mathrm{C}_{6} \mathrm{H}_{3}\right), 130.06\left(o-\mathrm{C}_{6} \mathrm{H}_{3}\right), 131.52$ $\left(p-\mathrm{C}_{6} \mathrm{H}_{3}-2,6-i \mathrm{Pr}_{2}\right), 134.20(\mathrm{C}=\mathrm{C}$, silacyclopentene $), 139.33\left(o-\mathrm{C}_{6} \mathrm{H}_{3}-2,6-i \mathrm{Pr}_{2}\right), 146.47(i-$ $\left.\mathrm{C}_{6} \mathrm{H}_{3}-2,6-i \mathrm{Pr}_{2}\right), 146,55\left(i-\mathrm{C}_{6} \mathrm{H}_{3}\right) .{ }^{29} \mathrm{Si} \mathrm{NMR}\left(119.1 \mathrm{MHz}, d^{8}\right.$-toluene, $\left.295 \mathrm{~K}\right): \delta=31.49$ ppm (quintet, ${ }^{2} \mathrm{~J}_{\mathrm{Si}-\mathrm{H}}=5.82 \mathrm{~Hz}$, silacyclopentene) IR (nujol, CsI plates, $\mathrm{cm}^{-1}$ ): 3020 (weak, broad), 1920 (weak, broad), 1598 (weak, sharp), 1580 (weak, sharp), 1562 (weak, sharp), 
1462 (strong, broad), 1380 (strong, medium), 1360 (strong, sharp), 1320 (weak, sharp), 1254 (weak, sharp), 1175 (strong, sharp), 1125 (weak, medium), 1056 (medium, sharp), 1038 (medium, sharp), 820 (weak, sharp), 804 (strong, sharp), 790 (strong, sharp), 755 (strong, medium), 722 (weak, medium), 702 (weak, sharp), 515 (weak, medium), 495 (medium, medium), 380 (weak, broad), 250 (medium, sharp).

\section{COMPUTATIONAL DETAILS}

The geometries of the model tetrylenes $\mathrm{E}(\mathrm{SPh})_{2}(\mathrm{E}=\mathrm{Si}, \mathrm{Ge}, \mathrm{Sn})$, ethylene, and the corresponding products $(\mathrm{SPh})_{2} \mathrm{ECH}_{2} \mathrm{CH}_{2}$ were fully optimized. Transition states connecting the two minima were searched with relaxed potential energy surface scans and optimizing the candidate structures (the ones with the highest energy) with a transition state search algorithm. Frequency calculations were then carried out to ensure that the stationary points found lie at true potential energy minima or show a single imaginary frequency corresponding to a vibration along the reaction coordinate (transition states). The interactions between the $\mathrm{E}(\mathrm{SPh})_{2}$ and ethylene fragments in the optimized products $(\mathrm{SPh})_{2} \mathrm{ECH}_{2} \mathrm{CH}_{2}$ were analyzed by the Ziegler-Rauk-Morokuma energy decomposition scheme (EDA). ${ }^{21}$

All geometry optimizations, potential energy surface scans, and frequency calculations were carried out with the Gaussian 09 program suite ${ }^{22}$ using density functional theory (DFT) in conjunction with the PBE0 exchange correlation functional ${ }^{23}$ and the def-TZVP basis sets. ${ }^{24} \mathrm{~A}$ corresponding large core effective core potential (ECP) basis set was used for the Sn atom. ${ }^{25}$ The EDA calculations were performed with the $A D F 2013.01$ suite of programs $^{26}$ using the PBE0 functional and the default TZ2P STO- 
type basis sets. ${ }^{27}$ Scalar relativistic effects were taken into account with the zeroth order regular approximation (ZORA) as implemented in $A D F .{ }^{28}$

\section{ASSOCIATED CONTENT}

Supporting Information. Spectral data and crystallographic details and CIFs for compounds $\mathbf{1}(\cdot 1.5 \mathrm{PhMe}), \mathbf{2}$, and $\mathbf{3}(\cdot 1.5 \mathrm{PhMe})$. Optimized geometries of the studied compounds and full details of the energy decomposition analyses. This material is available free of charge via the Internet at http://pubs.acs.org.

\section{AUTHOR INFORMATION}

E-mail for P. P. P.: pppower@ucdavis.edu

\section{ACKNOWLEDGEMENTS}

We are grateful to the U. S. Department of Energy (DE-FG02-07ER46475; P. P. P.) and Academy of Finland (H. M. T.) for funding. F. L. thanks the Alexander von Humboldt Foundation for a Feodor Lynen research fellowship. A. M. thanks the Foundation for Research of Natural Resources in Finland for a graduate scholarship (research grant to H. M. T.). 


\section{REFERENCES}

1. Franz, A. K.; Woerpel, K. A. Acc. Chem. Res. 2000, 33, 813.

2. Ando, W.; Kabe, Y. In The Chemistry of Organic Silicon Compounds, Rappoport, Z.; Apeloig, Y. (Eds.); Wiley: Chichester, UK, 1998; p. 2401.

3. a) Kinnaird, J. W. A.; Ng, P. Y.; Kubota, K.; Wang, X.; Leighton, J. L. J. Am. Chem. Soc. 2002, 124, 7920; b) Wang, X.; Meng, Q.; Nation, A. J.; Leighton, J. L. J. Am. Chem. Soc. 2002, 124, 10672; c) Berger, R.; Rabbat, P. M. A.; Leighton, J. L. J. Am. Chem. Soc. 2003, 125, 9596.

4. Conlin, R. T.; Gaspar, P. P. J. Am. Chem. Soc. 1976, 98, 3715.

5. Seyferth, D.; Annarelli, D. C.; Vick, S. C. J. Am. Chem. Soc. 1976, 98, 6382.

6. Gaspar, P. P.; West, R. In The Chemistry of Organic Silicon Compounds; Rappoport, Z., Apeloig, Y., Eds.; Wiley: Chichester, 1998.

7. a) Lambert, R. L.; Seyferth, D. J. Am. Chem. Soc. 1972, 94, 9246; b) Seyferth, D.; Annarelli, D. C.; J. Am. Chem. Soc. 1975, 97, 2273; c) Seyferth, D. J. Organomet. Chem. 1975, 100, 237.

8. a) Zhang, S.; Wagenseller, P.-E.; Conlin, R. T. J. Am. Chem. Soc. 1991, 113, 4278; b) Zhang, S.; Conlin, R. T. J. Am. Chem. Soc. 1991, 113, 4272; c) Boudjouk, P.; Blark, E.; Kumarathasan, R. Organometallics 1991, 10, 2095; d) Pae, D.-H.; Xiao, M.; Chiang, M. Y.; Gaspar, P. P. J. Am. Chem. Soc. 1991, 113, 1281.

9. a) Barton, T. J.; Burns, S. A.; Gaspar, P. P.; Chen, Y. S. Synth. React. Inorg. Met.Org. Chem. 1983, 13, 881; b) Lei, D.; Gaspar, P. P. Res. Chem. Intermed. 1989, 12, 103; c) Bobbitt, K. L.; Gaspar, P. P. J. Organomet. Chem. 1995, 499, 17. 
10. Ishida, S.; Iwamoto, T. ; Kira, M. Heteroat. Chem. 2011, 22, 432.

11. Rekken, B. D.; Brown, T. M.; Fettinger, J. C.; Tuononen, H. M.; Power, P. P. J. Am. Chem. Soc. 2012, 134, 6504.

12. Rekken, B. D.; Brown, T. M.; Fettinger, J. C.; Lips, F.; Tuononen, H. M.; Herber, R. H.; Power, P. P. J. Am. Chem. Soc. 2013, 135, 10134.

13. Lips, F.; Fettinger, J. C.; Mansikkamäki, A.; Tuononen, H. M.; Power, P. P. J. Am. Chem. Soc. 2014, 136, 634.

14. http://en.wikipedia.org/wiki/Ethylene.

15. (a) Azhakar, R.; Roesky, H. W.; Wolf, H.; Stalke, D. Z. Anorg. Allg. Chem. 2013, 639, 934. (b) Ohshita, J.; Honda, N.; Nada, K.; Iida, T.; Mihara, T.; Matsuo, Y.; Kunai, A.; Naka, A.; Ishikawa, M. Organometallics 2003, 22, 2436. (c) Yao, S.; Xiong, Y.; van Wullen, C.; Driess, M. Organometallics 2009, 28, 1610. (d) Yao, S.; van Wuellen, C.; Sun, X.-Y.; Driess, M. Angew. Chem. Int. Ed. 2008, 47, 3250. (e) Jiang, P.; Trieber II, D.; Gaspar, P. P. Organometallics 2003, 22, 2233. (f) Suzuki, K.; Matsuo, T.; Hashizume, D.; Tamao, K. J. Am. Chem. Soc. 2011, 133, 19710. (g) Sekiguchi, A.; Tanaka, T.; Ichinohe, M.; Akiyama, K.; TeroKubota, S. J. Am. Chem. Soc. 2003, 125, 4962. (h) Tsutsui, S.; Sakamoto, K.; Kabuto, C.; Kira M. Organometallics 1998 17, 3819. (i) Ostendorf, D.; Kirmaier, L.; Saak, W.; Marsmann, H.; Weidenbruch, M. Eur. J. Inorg. Chem. 1999, 2301. (j) Gasper, P. P.; Beatty, A. M.; Chen, T.; Haile, T.; Lei, D.; Winchester, W. R.; Braddock-Wilking, J.; Rath, N. P.; Klooster, W. T.; Koetzle, T. F.; Mason, S. A.; Albinati, A. Organometallics 1999, 18, 3921. (k) Gau, D.; Rodriguez, R.; Kato, T.; Saffon-Merceron, N.; Baceiredo, A. J. Am. Chem. Soc. 2010, 132, 12841. (1) 
Azhakar, R.; Roesky, H. W.; Ghadwal, R. S.; Holstein, J. J.; Dittrich, B. Dalton

Trans. 2012, 41, 9601. (m) Ohshita, J.; Ohnishi, H.; Naka, A.; Senba, N.; Ikadai, J.; Kunai, A.; Kobayashi, H.; Ishikawa, M. Organometallics 2006, 25, 3955. (n) Kunai, A.; Matsuo, Y.; Ohshita, J.; Ishikawa, M.; Aso, Y.; Otsubo, T.; Ogura, F. Organometallics 1995, 14, 1204.

16. Xiong, Y.; Yao, S.; Driess, M. Organometallics 2010, 29, 987.

17. Haaf, M.; Schmedake, T. A; Paradise, B. J.; West, R. Can. J. Chem. 2000, 78, 1526.

18. Toulokhonova, I. S.; Friedrichsen, D. R.; Hill, N. J.; Muller, T.; West, R. Angew. Chem. Int. Ed. 2006, 45, 2578.

19. Allred, A. L.; Rochow, E. G. J. Inorg. Nucl. Chem. 1958, 5, 264.

20. Jacobsen, H.; Ziegler, T. Comments Inorg. Chem. 1995, 17, 301.

21. (a) Morokuma, K. J. Chem. Phys. 1971, 55, 1236. (b) Kitaura, K.; Morokuma, K. Int. J. Quantum Chem. 1976, 10, 325. (c) Ziegler, T.; Rauk, A. Theor. Chim. Acta 1977, 46, 1.

22. Frisch, M. J.; Trucks, G. W.; Schlegel, H. B.; Scuseria, G. E.; Robb, M. A.; Cheeseman, J. R.; Scalmani, G.; Barone, V.; Mennucci, B.; Petersson, G. A.; Nakatsuji, H.; Caricato, M.; Li, X.; Hratchian, H. P.; Izmaylov, A. F.; Bloino, J.; Zheng, G.; Sonnenberg, J. L.; Hada, M.; Ehara, M.; Toyota, K.; Fukuda, R.; Hasegawa, J.; Ishida, M.; Nakajima, T.; Honda, Y.; Kitao, O.; Nakai, H.; Vreven, T.; Montgomery, J. A., Jr.; Peralta, J. E.; Ogliaro, F.; Bearpark, M.; Heyd, J. J.; Brothers, E.; Kudin, K. N.; Staroverov, V. N.; Kobayashi, R.; Normand, J.; Raghavachari, K.; Rendell, A.; Burant, J. C.; Iyengar, S. S.; Tomasi, J.; Cossi, M.; Rega, N.; Millam, J. M.; Klene, M.; Knox, J. E.; Cross, J. B.; Bakken, V.; Adamo, C.; Jaramillo, J.; Gomperts, R.; Stratmann, R. E.; Yazyev, O.; Austin, A. J.; Cammi, R.; Pomelli, C.; Ochterski, J. W.; Martin, R. L.; Morokuma, K.; Zakrzewski, V. G.; Voth, G. A.; Salvador, P.; Dannenberg, J. J.; Dapprich, S.; 
Daniels, A. D.; Farkas, Ö.; Foresman, J. B.; Ortiz, J. V.; Cioslowski, J.; Fox, D. J. Gaussian 09, Revision C.1; Gaussian, Inc., Wallingford, CT, 2009.

23. (a) Perdew, J. P.; Burke, K.; Ernzerhof, M. Phys. Rev. Lett. 1996, 77, 3865. (b) Perdew, J. P.; Ernzerhof, M.; Burke, K. J. Chem. Phys. 1996, 105, 9982. (c) Perdew, J. P.; Burke, K.; Ernzerhof, M. Phys. Rev. Lett. 1997, 78, 1396. (d) Adamo, C.; Barone, V. J. Chem. Phys. 1999, 110, 615.

24. Schaefer, A.; Huber, C.; Ahlrichs, R. J. Chem. Phys. 1994, 100, 5829.

25. Bergner, A.; Dolg, M.; Kuechle, W.; Stoll, H.; Preuss, H. Mol. Phys. 1993, 80, 1431.

26. ADF2013.01; SCM, Theoretical Chemistry, Vrije Universiteit, Amsterdam, The Netherlands; http://www.scm.com.

27. van Lenthe, E.; Baerends, E. J. J. Comput. Chem. 2003, 24, 1142.

28. (a) van Lenthe, E.; Baerends, E. J.; Snijders, J. G. J. Chem. Phys. 1993, 99, 4597.

(b) van Lenthe, E.; Baerends, E. J.; Snijders, J. G. J. Chem. Phys. 1994, 101, 9783. (c) van Lenthe, E.; Ehlers, A. E.; Baerends, E. J. J. Chem. Phys. 1999, 110, 8943. 